\title{
Analisis Pengaruh Pembelajaran Discovery terhadap Minat dan Hasil Belajar Asam Basa Peserta Didik
}

\author{
Sugiarti Sugiarti \\ Pendidikan Kimia, Universitas Negeri Makassar \\ Email: atisugiarti34@yahoo.co.id \\ Netti Herawati \\ Pendidikan Kimia, Universitas Negeri Makassar \\ Email: nettyherawati@gmail.com \\ Risdawati Risdawati \\ Pendidikan Kimia, Universitas Negeri Makassar \\ Email: risdawati426@gmail.com
}

(Diterima: 14-Desember-2019; direvisi: 15-Januari-2020; dipublikasikan: 14-Maret-2020)

\begin{abstract}
Abstrak: Penelitian ini adalah penelitian eksperimen semu yang bertujuan untuk mengetahui ada tidaknya pengaruh model pembelajaran discovery terhadap minat dan hasil belajar peserta didik kelas XI MIA SMAN 3 Pinrang. Variabel bebas dalam penelitian ini adalah model pembelajaran discovery dan pembelajaran langsung dan variabel terikatnya adalah minat dan hasil belajar peserta didik pada materi asam basa. Populasi dalam penelitian ini adalah seluruh peserta didik kelas XI MIA SMAN 3 Pinrang sebanyak enam kelas. Sampel penelitian ini adalah kelas XI MIA 5 sebagai kelompok eksperimen dengan jumlah peserta didik sebanyak 31 orang dan kelas XI MIA 2 sebagai kelompok kontrol dengan jumlah peserta didik sebanyak 33 orang. Data hasil penelitian diperoleh dengan memberikan angket minat dan tes hasil belajar pada materi pokok asam basa berupa post-test. Teknik analisis data dilakukan dengan statistik deskriptif dan statistik inferensial (uji-t). Hasil pengujian hipotesis untuk minat belajar menggunakan uji-t diperoleh nilai $\mathrm{t}_{\mathrm{hitung}}=3,025$ pada taraf $\alpha=0,05$ dengan $\mathrm{dk}=3$ dan nilai $t_{\text {tabel }}=1,66$ kriteria $t_{\text {hitung }}>t_{\text {tabel }}$ hal ini menunjukkan bahwa Ho ditolak dengan demikian terdapat pengaruh model pembelajaran discovey terhadap minat belajar peserta didik kelas XI MIA SMAN 3 Pinrang. Selanjutnya untuk pengujian hipotesis hasil belajar menggunakan uji Maan-Whitney diperoleh nilai $\mathrm{z}_{\mathrm{hitung}}=3,48$ pada taraf $\alpha=0,05$ dan nilai $\mathrm{z}_{\text {tabel }}=1,64$. Hal ini menunjukkan bahwa ada pengaruh model pembelajaran discovey terhadap hasil belajar peserta didik kelas XI MIA SMAN 3 Pinrang. Hasil pengujian korelasi pada kelompok eksperimen nilai $r_{\text {hitung }}=0,618$ pada taraf $\alpha=0,05$ dan $r_{\text {tabel }}=0,355$ sehingga dapat disimpulkan bahwa terdapat korelasi positif minat dan hasil belajar peserta didik kelas XI MIA ${ }_{5}$ dengan model pembelajaran discovery. Selanjutnya pengujian korelasi kelompok kontrol nilai $\mathrm{r}_{\text {hitung }}=$ 0,488 pada taraf $\alpha=0,05$ dan $r_{\text {tabel }}=0,344$ sehingga dapat disimpulkan bahwa terdapat korelasi positif antara minat dan hasil belajar peserta didik kelas XI MIA 2 dengan model pembelajaran langsung.
\end{abstract}

Kata kunci: Discovery Learning; Minat Belajar; Hasil Belajar; Asam Basa.

Abstract: This research is a quasi-experimental that aimed to find out the effect of discovery learning model toward interests and learning outcomes of students in class XI MIA SMAN 3 Pinrang. Independent variable in the research is discovery learning model and direct instruction and dependent variables is areinterest and learning outcomes of acid-base. The population in this research is all students class XI MIA SMAN 3 Pinrang that consist of six 
classes. Class XI MIA 5 as an experiment group that consist of 31 students and class XI MIA 2 as a control group that consist of 33 students. The result data of the research was obtained by interest questionnaires and learning outcomes test on acid-base topic for post test. Data were analysed using descriptive statistics and inferential statistics. The results of hypothesis testing for interest using t-test values obtained at $\mathrm{t}_{\text {count }}=3,025$ and significance level $\alpha=0,05$ with $\mathrm{df}=3$ and $\mathrm{t}_{\text {table }}=1,66$ because $\mathrm{t}_{\text {count }}>\mathrm{t}_{\text {table }}$ it indscate that $\mathrm{H}_{0}$ failed. So the are is effect learning model effect learning model to learning interets of students class XI MIA SMAN 3 Pinrang. While for testing the learning outcomes using Mann-Whitney test obtained at $\mathrm{Z}_{\text {count }}=3,48$ and significance level $\alpha=0,05$ with $\mathrm{df}=3$ and $\mathrm{z}_{\text {table }}=1,64$. It shows that there is the effect of discovery learning model toward learning outcomes of students in class XI MIA SMAN 3 Pinrang. Testing correlation for experiment group is obtained $r_{\text {count }}=0,618$ on significance level $\alpha=0,05$ and $r_{\text {table }}=0,355$, so it can be concluded that there is positive correlation interests with learning outcomes in discovery learning model. While testing correlation for control group is obtained $r_{\text {count }}=0,488$ on significance level $\alpha=0,05$ and $r_{\text {table }}=0,344$, so it can be concluded that there is positive correlation interests and learning outcomes in direct instruction.

Keywords: Discovery Learning; Interest; Learning Outcomes; Acid Base.

\section{PENDAHULUAN}

Penekanan pelaksanaan pembelajaran untuk mengaktifkan peserta didik belajar menemukan sendiri konsep materi merupakan salah satu cara tepat mengantarkan peserta didik mengerti pelajarannya, termasuk pelajaran kimia yang semakin hari semakin banyak peserta didik yang merasa kesulitan mempelajarinya dan tidak memiliki ketertarikan untuk mempelajarinya. Alasannya, pelajaran kimia tidak dapat dipelajari sendiri sebagaimana pelajaran serumpun lainnya. Pernyataan ini diperkuat dengan tujuan kurikulum 2013 dengan menggunakan model-model pembelajaran seperti model inquiry learning, discovery learning, dan problem based learning.

Model pembelajaran discovery pada dasarnya meerupakan model penemuan yang sangat cocok untuk semua materi pelajaran sebab model ini terdiri atas enam sintaks yang didahului dengan stimulus. Stimulus ini meransang keingin tahuan peserta didik dan menimbulkan ketertarikan dan minat tersendiri untuk menelusuri masalah yang timbul. Peserta didik lebih aktif dalam belajar berkelompok sampai membuat kesimpulan sendiri. Manfaat pembelajaran dengan model discovery terbukti dapat berpengaruh terhadap hasil belajar peserta didik pada aspek pengetahuan dan keterampilan (Kurnianto, 2016). Pada model ini kegiatan untuk mengkonstruk pengetahuan berlangsung secara bertahap dengan mengikuti sintaks dari model tersebut.

Hasil observasi aktivitas, minat dan hasil belajar peserta didik SMAN 3 Pinrang khususnya kelas XI MIA tahun ajaran 2017/2018 diperoleh fakta bahwa pembelajaran yang diterapkan guru masih bersifat ceramah, teacher centered, tidak berminat belajar kimia, dan hasil belajar peserta didik sangat rendah tidak memenuhi KKM 75. Menurut tanggapan mereka, materi larutan asam basa membutuhkan pemahaman konsep, penggunaan rumus dan dibutuhkan keterampilan berhitung dan sulit dipelajari sendiri. Peserta didik cenderung pasif, sehingga kurang memicu minat belajar peserta didik.

Beberapa jenis minat belajar yang seharusnya muncul setiap pembelajaran berlangsung seperti perasaan senang, perhatian, ketertarikan dan keaktifan. Melalui minat akan menggerakkan motivasi seseorang untuk berkonsentrasi belajar sehingga dapat dikatakan bahwa dengan minat yang baik akan mempengaruhi hasil belajar menjadi lebih baik pula (Susanto, 2013). 
Berdasarkan latar belakang di atas, penulis tertarik mengangkat penelitian ini yang diformulasikan dengan judul: "Analisis Pengaruh Pembelajaran Discovery terhadap Minat dan Hasil Belajar Asam Basa Peserta Didik SMAN 3 Pinrang". Untuk itu beberapa rumusan masalah dirumuskan menjadi: (1) Apakah ada pengaruh model pembelajaran discovery terhadap minat belajar?, (2) Apakah ada pengaruh model pembelajaran discovery terhadap hasil belajar?, (3) Apakah ada korelasi antara minat dan hasil belajar peserta didik dalam model pembelajaran discovery?, dan (4) Apakah ada korelasi antara minat dan hasil belajar asam basa dalam model pembelajaran discovery bagi Peserta didik Kelas XI SMAN 3 Pinrang?.

\section{METODE}

Penelitian ini merupakan penelitian eksperimen semu. Desain penelitian yang digunakan adalah Posttest-Only Control Design yang melibatkan dua elas yang dipilih secara random berupa kelas eksperimen dan kelas kontrol. Variabel penelitiannya terdiri atas variabel bebas dan terikat. variabel bebasnya yaitu model pembelajaran discovery dan model pembelajaran langsung, sedangkan yang menjadi variabel terikat adalah minat dan hasil belajar pada materi asam basa.

Populasi penelitian ini adalah seluruh peserta didik kelas XI SMAN 3 Pinrang tahun ajaran 2018/2019 yang terdiri atas enam kelas dengan jumlah peserta didik 193 orang. Sampel dalam penelitian ini diambil secara random, dan terpilih dua kelas sebagai kelas eksperimen yaitu kelas XI MIA 5 dan kelas kontrol adalah kelas XI MIA 2 SMAN 3 Pinrang.

Instrumen yang digunakan untuk mengumpulkan data dalam penelitian ini adalah instrumen angket minat belajar yang terdiri atas empat indikator yang diurai menjadi 24 item soal. Tes hasil belajar untuk mengetahui kemampuan kognitif asam basa yang terdiri atas 20 butir soal pilihan ganda yang telah diuji validitasnya dengan menggunakan validitas item dan validitas isi. Selain itu menggunakan lembar observasi aktivitas belajar peserta didik pada proses pembelajaran discovery.

Teknik analisis data yang digunakan adalah teknik analisis statistik deskriptif dan inferensial. Analisis statistik deskriptif untuk memberikan gambaran tentang karakteristik pencapaian minat belajar dan hasil belajar. Angket minat dianalisis dengan menggunakan skala likert dalam bentuk kategori; sangat tinggi, tinggi, sedang, rendah dan sangat rendah. Pencapaian hasil belajar dilihat dari ketuntasan nilai pada kategori tuntas dengan nilai $>75$, dan tidak lulus dengan nilai $<75$.

Analisis statistik inferensial digunakan untuk menguji hipotesis penelitian menggunakan uji-t (Sugiyono, 2000) untuk minat, dan menggunakan Mann-Whitney sebab uji prasyarat normalitas dan homogenitas tidak memenuhi normal dan homogen. Pada hipotesis hubungan antara minat dan hasil belajar digunakan uji korelasi produk moment (Sugiyono, 2014).

\section{HASIL DAN PEMBAHASAN}

Hasil penelitian yang disajikan meliputi hasil analisis statistik deskriptif berupa gambaran umum karakteristik pencapaian minat belajar dan hasil belajar peserta didik pada kelompok kelas eksperimen dan kontrol. Adapun nilai statistik minat belajar peserta didik dapat dilihat pada Tabel 1. Sedangkan nilai statistik hasil belajar peserta didik dapat dilihat pada Tabel 2.

Tabel 1. Nilai Statistik Minat Belajar Peserta Didik

\begin{tabular}{|c|c|c|}
\hline \multirow{2}{*}{ Statistik } & \multicolumn{2}{|c|}{ Nilai Statistik } \\
\hline & Kelompok Eksperimen & Kelompok Kontrol \\
\hline Jumlah Sampel & 31 & 33 \\
\hline
\end{tabular}




\begin{tabular}{ccc}
\hline \multirow{2}{*}{ Statistik } & \multicolumn{2}{c}{ Nilai Statistik } \\
\cline { 2 - 3 } & Kelompok Eksperimen & Kelompok Kontrol \\
\hline Nilai Tertinggi & 91 & 88 \\
Nilai Terendah & 68 & 58 \\
Rata-rata & 77,35 & 72,51 \\
Standar Deviasi & 5,97 & 6,78 \\
\hline
\end{tabular}

Tabel 2. Nilai Statistik Hasil Belajar Peserta Didik

\begin{tabular}{ccc}
\hline \multirow{2}{*}{ Statistik } & \multicolumn{2}{c}{ Nilai Statistik } \\
\cline { 2 - 3 } & Kelompok Eksperimen & Kelompok Kontrol \\
\hline Jumlah Sampel & 31 & 33 \\
Nilai Tertinggi & 95 & 80 \\
Nilai Terendah & 55 & 40 \\
Rata-rata & 74,03 & 65,27 \\
Standar Deviasi & 9,93 & 11,66 \\
\hline
\end{tabular}

Kedua tabel di atas menunjukkan bahwa nilai rata-rata untuk minat dan hasil belajar yang diperoleh kelompok eksperimen lebih tinggi dibandingkan kelompok kontrol. Adapun analisis statistik inferensial digunakan untuk menguji hipotesis penelitian. Pada analisis statistik inferensial ada tiga pengujian yang digunakan yaitu uji normalitas, uji homogenitas, dan uji statistik parametrik (uji-t). Pada pengujian prasyarat analisis minat belajar, uji normalitas menggunakan statistik uji chi-kuadrat, hasil perhitungan pada kelompok eksperimen diperoleh nilai $X^{2}$ hitung untuk kelas eksperimen dan kontrol sebesar 5,47 dan 1,644, dan $X_{\text {tabel }}^{2}$ untuk kelas eksperimen dan kontrol sebesar 7,815 pada taraf kepercayaan $(\alpha)=0,05$ dan derajat kebebasan $(\mathrm{dk})=3$, dapat disimpulkan bahwa sampel pada kelompok eksperimen dan kontrol terdistribusi normal.

Kriteria pengujian homogenitas adalah jika $F_{\text {hitung }}<F_{\text {tabel }}$ maka kedua kelompok sampel berasal dari populasi yang homogen. Hasil uji homogenitas diperoleh data $F_{\text {hitung }}=1,261$ sedangkan pada taraf kepercayaan $(\alpha)=0,05$ diperoleh $\mathrm{F}_{\text {tabel }}=$ 1,837 sehingga dapat disimpulkan bahwa minat belajar kelompok eksperimen dan kelompok kontrol bersifat homogen.

Berdasarkan hasil uji prasyarat diketahui bahwa data angket minat dari kelompok eksperimen dan kelompok kontrol terdistribusi normal, serta kedua kelompok berasal dari populasi yang homogen, maka dilanjutkan dengan uji statistik parametrik, yaitu uji-t.

Hasil analisis uji-t menunjukkan nilai $\mathrm{t}_{\text {hitung }}=3,02$ dan nilai $\mathrm{t}_{\text {tabel }}$ pada taraf kepercayaan 0,05 adalah 1,66 maka $\mathrm{H}_{0}$ ditolak dan $\mathrm{H}_{1}$ diterima berarti ada pengaruh penggunaan model pembelajaran discovery terhadap minat belajar peserta didik kelas XI MIA SMAN 3 Pinrang pada materi pokok asam basa. Selanjutnya pengujian prasyarat analisis hasil belajar, uji normalitas menggunakan statistik uji chi-kuadrat, data dikatakan normal apabila $X^{2}$ hitung $X<^{2}{ }_{\text {tabel }}$. Hasil perhitungan pada kelompok eksperimen diperoleh nilai $X_{\text {hitung }}^{2}=6,39$ dan kelompok kontrol $X^{2}$ hitung $=12,27$. Nilai untuk $\chi_{\text {tabel }}^{2}$ pada taraf kepercayaan $(\alpha)=$ 0,05 dan derajat kebebasan $(d k)=3$ adalah 7,815, kelompok eksperimen terdistribusi normal dan kelompok kontrol tidak terdistribusi normal.

Kriteria pengujian homogenitas adalah jika $F_{\text {hitung }}<F_{\text {tabel }}$ maka kedua kelompok sampel berasal dari populasi yang homogen. Hasil uji homogenitas diperoleh data $F_{\text {hitung }}=1,380$ taraf kepercayaan $(\alpha)=$ 0,05 diperoleh $\mathrm{F}_{\text {tabel }}=1,837$ berarti hasil belajar kelompok eksperimen dan kelompok kontrol bersifat homogen. Berdasarkan hasil uji prasyarat diketahui bahwa data angket 
minat dari kelompok eksperimen terdistribusi normanl dan kelompok kontrol tidak terdistribusi normal, serta kedua kelompok berasal dari populasi yang homogen, maka dilanjutkan dengan uji statistik non-parametrik, yaitu uji Mann Whitney. Hasil analisis uji Mann Whitney menunjukkan nilai Zhitung $=3,48$ dan nilai $\mathrm{Z}_{\text {tabel }}$ pada taraf kepercayaan 0,05 adalah 1,64 maka $\mathrm{H}_{0}$ ditolak dan $\mathrm{H}_{1}$ diterima berarti ada pengaruh penggunaan model pembelajaran discovery terhadap hasil belajar peserta didik kelas XI MIA SMAN 3 Pinrang pada materi pokok asam basa.

Berdasarkan uji linearitas antara minat dan hasil belajar peserta didik kelompok eksperimen diperoleh nilai $\mathrm{F}_{\text {hitung }}$ $=1,72$ dan nilai $\mathrm{F}_{\text {tabel }}$ pada taraf kepercayaan 0,05 adalah 4,18 dengan model regrasi $\hat{Y}=$ $43,762+0,40$ dan untuk kelompok kontrol diperoleh nilai $\mathrm{F}_{\text {hitung }}=1,65$ dan nilai $\mathrm{F}_{\text {tabel }}$ pada taraf kepercayaan 0,05 adalah 2,41 dengan model regrasi $\hat{Y}=10,07+0,76$ terdapat hubungan linear minat dan hasil belajar pada kelompok eksperimen dan kelompok kontrol. Berdasarkan uji korelasi minat dan hasil belajar peserta didik kelompok eksperimen dan kelompok kontrol diperoleh nilai $\mathrm{r}_{\text {hitung }}=0,949$ dan nilai $\mathrm{F}_{\text {tabel }}$ pada taraf kepercayaan 0,05 adalah 0,344 sehingga dapat disimpulkan bahwa terdapat hubungan korelasi positif antara minat dan hasil belajar pada kelompok eksperimen dan kelompok kontrol dengan nilai product moment 0,488 dengan kategori sedang.

\section{Pengaruh Penggunaan Model Pembelajaran Discovery terhadap Minat Belajar Peserta Didik}

Hasil analisis deskriptif
menunjukkan bahwa adanya perbedaan minat belajar antara kelompok eksperimen dan kelompok kontrol diperoleh bahwa nilai rata-rata minat belajar peserta didik pada kelompok eksperimen lebih tinggi dibandingkan kelompok kontrol. Perlakuan yang diberikan untuk masing-masing kelompok mengakibatkan terjadinya perbedaan minat belajar peserta didik pada kedua kelompok tersebut. Berdasarkan analisis indikator minat belajar diperoleh bahwa persentase kategori keempat indikator minat belajar lebih tinggi pada kelompok ekperimen dengan model discovery dibandingkan kelompok kontrol dengan model pembelajaran langsung. Pada indikator pertama yaitu perasaan senang diperoleh bahwa pengkategorian minat belajar peserta didik lebih baik pada model pembelajaran discovery dibandingkan model pembelajaran langsung, hal ini dikarenakan karena peserta didik dapat membuat rumusan masalah melalui tukar pikiran dengan teman kelompok sehingga peserta didik tidak akan tertekan dengan pertanyaan yang akan dilontarkan oleh guru. Indikator kedua yaitu perhatian diperoleh bahwa pengkategorian minat belajar kelompok eksperimen lebih baik dibandingkan kelompok kontrol karena pada kelompok eksperimen peserta didik dituntut untuk berdiskusi secara aktif dan kreatif menemukan dan mengkonstruk sendiri pembelajaran untuk menyelesaikan masalah yang telah dirumuskan sehingga peserta didik akan lebih memperhatikan pembelajaran.

Indikator ketiga yaitu antusiasme diperoleh bahwa pengkategorian minat pada indikator ini lebih baik pada kelompok eksperimen dibandingkan kelompok kontrol, hal ini karena pada model pembelajaran discovery untuk tahap pembuktian tiap kelompok akan memaparkan hasil diskusi kelompoknya, maka peserta didik akan berlomba menampilkan yang terbaik untuk memperoleh nilai tertinggi. Indikator keempat keterlibatan diperoleh bahwa pengkategorian minat pada indikator ini lebih baik pada kelompok eksperimen dibandingkan kelompok kontrol karena model pembelajaran discovery melibatkan peserta didik secara aktif dalam setiap tahapan pembelajaran mulai dari perumusan masalah hingga penarikan kesimpulan.

Pengujian analisis prasyarat untuk memperkuat hasil analisis deskriptif, dilakukan analisis lebih lanjut yaitu analisis statistik inferensial yang bertujuan untuk membuktikan kebenaran dari hipotesis yang diajukan. Uji normalitas pada kelompok 
eksperimen diperoleh nilai $\chi_{\text {hitung }}^{2} \leq \chi_{\text {tabel, }}^{2}$ sehingga disimpulkan bahwa sampel pada kelompok eksperimen terdistribusi normal Sedangkan pada kelompok kontrol diperoleh nilai $\chi_{\text {hitung }}^{2}>\chi_{\text {tabel sehingga dapat }}^{2}$ disimpulkan bahwa sampel pada kelompok kontrol tidak terdistribusi normal. Selanjutnya dilakukan uji homogenitas diperoleh $F_{\text {hitung }}<\mathrm{F}_{\text {tabel }}$ sehingga dapat disimpulkan bahwa kelompok eksperimen dan kelompok kontrol berasal dari populasi yang homogen.

Hasil pengujian hipotesis untuk minat belajar diperoleh nilai $\mathrm{t}_{\text {hitung }}>\mathrm{t}_{\text {tabel }}$. Hal ini menunjukkan $H_{o}$ ditolak dan $H_{l}$ diterima yang berarti hipotesis yang diajukan diterima yakni ada pengaruh positif penggunaan model pembelajaran discovery terhadap minat belajar peserta didik kelas XI MIA SMAN 3 Pinrang pada materi pokok asam basa. Hal ini sesuai dengan penelitian terkait peningkatan minat belajar ini dapat disebabkan oleh model pembelajaran yang diterapkan Astuti (2017). Penerapan model pembelajaran discovery yang dapat meningkatkan minat belajar peserta didik Puspitadewi (2016). Dengan adanya minat belajar, akan menjadi pendorong seseorang untuk memberikan perhatian dan selanjutnya akan berdampak pada tindakan nyata untuk hal yang akan dilakukan.

\section{Pengaruh Penggunaan Model Pembelajaran Discovery terhadap Hasil Belajar Peserta Didik}

Analisis deskriptif hasil belajar peserta didik menunjukkan bahwa nilai ratarata hasil belajar peserta didik pada kelompok eksperimen yang menggunakan model pembelajaran discovery lebih tinggi dibandingkan kelompok kontrol dengan model pembelajaran langsung. Berdasarkan analisis ketuntasan kelas diperoleh bahwa ketuntasan kelas eksperimen memiliki persentase $66 \%$ dan kelompok kontrol 33\%.

Berdasarkan data pencapaian ketuntasan rata-rata indikator hasil belajar kelompok eksperimen lebih tinggi dibandingkan dengan kelompok kontrol. Adapun untuk indikator pertama yaitu menjelaskan konsep asam dan basa menurut
Arrhenius diperoleh nilai persentase ketuntasan kelompok eksperimen lebih tinggi dibandingkan kelompok kontrol hal ini dikarenakan peserta didik sendiri yang menemukan konsep melalui keterlibatan aktif dalam proses pembelajaran sehingga pembelajaran akan lebih mudah untuk dipahami. Untuk indikator ketiga menjelaskan persamaan reaksi asam dan basa menurut Bronsted- Lowry peserta didik yang dibelajarkan dengan model pembeajaran discovery mencapai kategori tuntas sedangkan pada kelompok kontrol tidak mencapai kategori ketuntasan, hal ini dikarenakan peserta didik pada kelompok eksperimen lebih aktif dalam menentukan pasangan asam basa konjugasi sedangkan pada kelompok kontrol peserta didik hanya terfokus pada contoh yang dijelaskan oleh guru tanpa ada latihan mengerjakan soal secara mandiri atau berkelompok.

Indikator keenam menjelaskan perbedaan asam kuat dengan asam lemah dan basa kuat dengan basa lemah beserta contohnya, diperoleh bahwa persentase ketuntasan kelompok eksperimen lebih tinggi dibandingkan kelompok kontrol, kelompok eksperimen mencapai kategori tuntas sedangkan kelompok kontrol tidak tuntas. Hal ini karena pada materi ini membutuhkan pemahaman konsep dan ketelitian yang tinggi, untuk kelompok eksperimen dengan model discovery pemahaman konsep peserta didik lebih baik dikarenakan peserta didik yang menemukan dan mengolah sendiri data yang diperoleh sehingga pemahaman akan konsep lebih baik sedangkan kelas kontrol peserta didik hanya terfokus pada materi yang diberikan guru yang terbatas tanpa mencari atau menemukan konsep sendiri dari sumber lain.

Adapun indikator dengan persentase ketuntasan paling kurang yaitu pada indikator kedelapan menentukan sifat asam basa suatu larutan berdasarkan hasil perhitungan $\mathrm{pH}$, diperoleh bahwa persentase pada kelompok eksperimen lebih rendah dibandingkan persentase pada kelompok kontrol dan keduanya berada pada kategori tidak tuntas, hal ini dikarenakan sebagian 
besar peserta didik sulit dalam mengaplikasikan rumus. Pada model pembelajaran discovery peserta didik kurang latihan dalam mengerjakan soal secara langsung sedangkan pada kelompok kontrol peserta didik hanya memahami cara pengaplikasian rumus yang diberikan oleh guru tanpa menggali lebih lanjut pengaplikasian rumus yang lain.

Pengujian analisis prasyarat untuk memperkuat hasil analisis deskriptif, dilakukan analisis lebih lanjut yaitu analisis statistik inferensial yang bertujuan untuk membuktikan kebenaran dari hipotesis yang diajukan. Berdasarkan uji normalitas diperoleh nilai $\chi_{\text {hitung }}^{2} \chi_{\text {tabel }}^{2}$ untuk kelompok eksperimen, sehingga disimpulkan bahwa sampel pada kelompok eksperimen terdistribusi normal. Sedangkan pada kelompok kontrol diperoleh nilai $\chi_{\text {hitung }}^{2}>\chi_{\text {tabel }}^{2}$ sehingga dapat disimpulkan bahwa sampel pada kelompok kontrol tidak terdistribusi normal. Hal ini menunjukkan bahwa pada kelompok kontrol data hasil belajar peserta didik tidak tersebar merata sehingga menghasilkan data tidak normal. Selanjutnya dilakukan uji homogenitas diperoleh $F_{\text {hitung }}<F_{\text {tabel }}$ sehingga dapat disimpulkan bahwa kelompok eksperimen dan kelompok kontrol berasal dari populasi yang homogen.

Hal ini sesuai dengan penelitian yang dilakukan oleh Yuliana (2018) bahwa dalam penerapan model pembelajaran discovery sangat membantu guru dalam upaya meningkatkan hasil belajar peserta didik. Penerapan model pembelajaran discovery sangat membantu dalam upaya meningkatkan hasil belajar peserta didik. Selain itu, model ini juga membantu dalam meningkatkan keaktifan guru dan peserta didik, kepercayaan diri peserta didik, dan kemampuan bekerja mandiri dalam pemecahan masalah.

\section{Korelasi antara Minat dan Hasil Belajar Peserta Didik}

Uji korelasi bertujuan untuk mengetahui adanya hubungan antara variabel minat dan hasil belajar peserta didik. Sebelum melakukan uji korelasi terlebih dahulu dilakukan uji linearitas, pada uji linearitas diperoleh bahwa nilai $F_{\text {hitung }}<$ $F_{\text {tabel }}$ yang berarti data minat dan hasil belajar bersifat linier. Pada pengujian hipotesis ini yaitu korelasi antara minat dan hasil belajar peserta didik untuk kelompok eksperimen dengan model pembelajaran discovery diperoleh nilai $r_{\text {hitung }}(0,618)>r_{\text {tabel }}$ $(0,355)$ menunjukan terdapat korelasi positif antara minat dan hasil belajar peserta didik pada kelompok eksperimen.

Nilai korelasi product moment $\left(\mathrm{r}_{\mathrm{xy}}\right)$ 0,618 dengan kategori tinggi hal ini menunjukkan bahwa dengan meningkatnya minat belajar peserta didik yang mengakibatkan hasil belajar peserta didik juga meningkat. Hal tersebut sejalan dengan penelitian yang dilakukan oleh (Widiyanto, 2013) yang menyatakan bahwa apabila minat belajar meningkat maka hasil belajar juga akan meningkat. Korelasi minat dan hasil belajar kelompok kontrol dengan model pembelajaran langsung diperoleh nilai $\mathrm{r}_{\text {hitung }}(0,488)>\mathrm{r}_{\text {tabel }}(0,344)$ menunjukan terdapat korelasi positif antara minat dan hasil belajar peserta didik pada kelompok kontrol. Nilai korelasi product moment $\left(\mathrm{r}_{\mathrm{xy}}\right)$ 0,488 dengan kategori sedang, hal ini menunjukkan bahwa korelasi pada kelompok eksperimen dengan model pembelajaran discovery lebih baik dibandingkan korelasi pada kelompok kontrol dengan model pembelajaran langsung.

Salah satu faktor internal yang sangat besar pengaruhnya terhadap proses belajar peserta didik adalah minat peserta didik itu sendiri, karena bila bahan pelajaran yang dipelajari tidak sesuai minat, maka peserta didik tidak akan belajar dengan sebaikbaiknya, karena tidak ada daya tarik baginya (Slameto, 2010). Pada model pembelajaran discovery peserta didik memiliki minat belajar yang lebih tinggi daripada peserta didik yang dibelajarkan dengan model pembelajaran langsung.

Pada Model discovery pembelajaran akan berpusat langsung pada peserta didik sehingga dapat meningkatkan minat belajar peserta didik dibandingkan pada model 
pembelajaran langsung yang berpusat pada guru mengakibatkan minat belajar peserta didik kurang sehingga akan berpengaruh pada hasil belajar peserta didik. Hal ini sesuai dengan penelitian oleh Damayanti (2016), terdapat pengaruh minat belajar terhadap hasil belajar serta adanya interaksi antara model pembelajaran dengan minat belajar dalam mempengaruhi hasil belajar peserta didik. Penerapan model pembelajaran discovery dapat meningkatkan minat dan hasil belajar peserta didik (Puspitadewi 2016).

Berdasarkan uraian di atas menunjukkan bahwa penggunaan model pembelajaran discovery berpengaruh positif terhadap minat belajar peserta didik. Indikator minat belajar yang paling berpengaruh adalah perasaan senang dan perhatian sedangkan untuk hasil belajar peserta didik penggunaan model pembelajaran discovery lebih berpengaruh baik dibandingkan dengan model pembelajaran langsung terutama pada indikator pertama menjelaskan konsep asam dan basa menurut Arrhenius, ketiga menjelaskan persamaan reaksi asam dan basa menurut Bronsted-Lowry, dan keenam menjelaskan perbedaan asam kuat dengan asam lemah dan basa kuat dengan basa lemah beserta contoh senyawanya. Maka dapat disimpulkan bahwa dengan meningkatnya minat belajar peserta didik akan selaras dengan peningkatan hasil belajarnya. Hal ini didukung oleh penelitian Agung dan Ashadi (2016) yang menyatakan bahwa penerapan model pembelajaran discovery dapat meningkatkan minat dan hasil belajar peserta didik.

\section{SIMPULAN DAN SARAN}

Berdasarkan hasil analisis dan pembahasan, maka dapat disimpulkan bahwa penggunaan model pembelajaran discovery berpengaruh positif terhadap minat dan hasil belajar peserta didik, terdapat korelasi positif antara minat belajar dan hasil belajar peserta didik dalam model pembelajaran discovery dan model pembelajaran langsung peserta didik kelas
XI MIA SMA Negeri 3 Pinrang pada materi pokok asam basa. Oleh karena itu, disarankan pada guru kimia dan peneliti selanjutnya lebih sungguh-sungguh menerapkan pembelajaran discovery sehingga semua indikator dapat berada pada kategori sangat tinggi.

\section{DAFTAR RUJUKAN}

Astuti, Puji, S., Mulyani, B., Utami, B. 2017. Penerapan Model Pembelajaran Teams Games Tournament (TGT) untuk Meningkatkan Minat Belajar dan Prestasi Belajar Siswa Kelas XI MIA 3 SMA AL ISLAM 1 Surakarta Tahun Ajaran 2015/2016. Jurnal Pendidikan Kimia, 2(6).

Damayanti, M., Anwar, M., Sugiarti. 2016. Pengaruh Model Pembelajaran dan Minat Belajar terhadap Hasil Belajar Kimia Peserta Didik Kelas XI IPA SMAN 1 Tinambung (Studi Materi Pokok Hidrolisis Garam). Jurnal Kimia.

Kurnianto, Hadi, Masykuri, M., Yamtinah, S. 2016. Pengaruh Model Pembelajaran Discovery Learning Disertai Lembar Kegiatan Siswa (LKS) terhadap Prestasi Belajar Siswa pada Materi Hidrolisis Garam Kelas XI SMAN 1 Karanganyar Tahun Pelajaran 2014/2015. Jurnal Pendidikan Kimia (JPK), 5(1).

Puspitadewi, R., Agung, N. C. S., \& Ashadi. 2016. Penerapan Model Pembelajaran Discovery Learning untuk Meningkatkan Minat dan Prestasi Belajar Siswa pada Materi Kelarutan dan Hasil Kali Kelarutan XI MIA 3 Semester Genap SMAN 1 Teras Tahun Pelajaran 2015/2016. Jurnal Pendidikan Kimia (JPK), 5(4).

Slameto. 2010. Belajar dan Faktor-Faktor yang Mempengaruhinya. Jakarta: Rineka Cipta.

Sugiyono. 2000. Metode Penelitian Bisnis. Bandung: CV Alfabeta. 
Sugiarti, Herawati, Risdawati. Analisis pengaruh pembelajaran....

Sugiyono. 2014. Metode Penelitian Pendidikan Pendekatan Kuantitatif, Kualitatif, dan R\&D. Bandung: Alfabeta.

Susanto, A. 2013. Teori Belajar dan Pembelajaran Di Sekolah Dasar. Jakarta: Kencana Prenada Media Group.

Widiyanto, Mikha, A. 2013. Statistika Terapan: Konsep \& Aplikasi SPSS dalam Penelitian Bidang Pendidikan, Psikologi, \& Ilmu Sosial Lainnya. Jakarta: Gramedia.

Yuliana, Nabila. 2018. Penggunaan Model Pembelajaran Discovery Learning dalam Peningkatan Hasil Belajar Siswa Di Sekolah Dasar. Jurnal Ilmiah Pendidikan dan Pembelajaran, 2615-6091. 